\title{
In Vitro and In Ovo Assessment of Betulinic Acid Antimelanoma Effect
}

\author{
Dorina Coricovac $^{1,2}$, Iulia Pînzaru ${ }^{1,2}$, Ștefana Avram ${ }^{2,3, *}$, Ioana Macaşoi ${ }^{1,2}$, \\ Codruța Şoica ${ }^{2,4}$ and Cristina Dehelean ${ }^{1,2}$ \\ ${ }^{1}$ Department of Toxicology and Drug Industry, Faculty of Pharmacy, "Victor Babes" University of Medicine and \\ Pharmacy, Eftimie Murgu Sq. no. 2, 30004I Timişoara, Romania; dorinacoricovac@umft.ro (D.C.); \\ iuliapinzaru@umft.ro (I.P.); macasoi.ioana@umft.ro (I.M.); cadehelean@umft.ro (C.D.) \\ ${ }^{2}$ Research Center for Pharmaco-Toxicological Evaluations, Faculty of Pharmacy, "Victor Babes" University of \\ Medicine and Pharmacy, Eftimie Murgu Sq. no. 2, 30004I Timișoara, Romania \\ 3 Department of Pharmacognosy, Faculty of Pharmacy, "Victor Babes" University of Medicine and Pharmacy, \\ Eftimie Murgu Sq. no. 2, 30004I Timișoara, Romania; stefana.avram@umft.ro \\ 4 Department of Pharmaceutical Chemistry, Faculty of Pharmacy, "Victor Babes" University of Medicine and \\ Pharmacy, Eftimie Murgu Sq. no. 2, 30004I Timișoara, Romania; codrutasoica@umft.ro \\ ${ }^{*}$ Correspondence: stefana.avram@umft.ro; Tel.: +40-722-542-528
}

Submitted: 24 September 2020; Accepted: 19 October 2020; Published: 26 October 2020

\begin{abstract}
Although it recorded a breakthrough for the treatment of metastatic melanoma in the last decade, this disease remains a challenge in terms of finding an efficient treatment, reducing secondary resistance to treatment, and understanding the complexity of the molecular mechanisms involved in its development, progression and metastasis. This study aims to verify the multitarget effect of a natural compound, betulinic acid (BA), a pentacyclic triterpene, as antimelanoma agent by applying two experimental models: a human melanoma cell line- $\mathrm{A}_{375}$ and the chick chorioallantoic membrane model. The methods applied in this study were: MTT cell viability assay for cytotoxicity assessment and the chorioallantoic membrane assay (CAM) for antiangiogenic evaluation. The results indicated a significant decrease of $A_{375}$ cells viability after a $72 \mathrm{~h} \mathrm{BA}$ treatment even at the lowest concentration tested-I $\mu \mathrm{M}$ (61.95\% viable cells), with a calculated IC50 of $9.437 \mu \mathrm{M}$. In addition, BA inhibited not only the in ovo $\mathrm{A}_{375}$-induced tumor growth but also the angiogenesis on the primary site at $72 \mathrm{~h}$ post application. These data highlight the potential antimelanoma effect of BA by targeting the tumor cells via multiples pathways as inducing cell death and suppressing the angiogenic process, a must have for tumor development.
\end{abstract}

Keywords: melanoma; betulinic acid; A $_{375}$ melanoma cell line; angiogenesis; cytotoxicity

How to cite: Coricovac, D.; Pînzaru, I.; Avram, Ș.; Macașoi, I.; Șoica, C.; Dehelean, C. In Vitro and In Ovo Assessment of Betulinic Acid Antimelanoma Effect. Timisoara Med. 2020, 2020(I), 6; doi:I0.35995/tmj20200106.

\section{Introduction}

Cutaneous melanoma is one of the most common type of melanoma that origins from the malignant transformation of the epidermal melanocytes (cells that generate melanin pigment) induced by ultraviolet radiation (UV)'s deleterious effects [I,2]. According to the report elaborated by the National Cancer Institute 
Surveillance, Epidemiology, and End Results Program (NCI-SEER) in 2019, melanoma represents the fifth most common type of cancer in men and women worldwide [3]. It is well-known that metastatic melanoma patients present a reduced rate of tumor regression, develop resistance to targeted treatment and have a low survival rate, features that could be related to the immunological character of this disease that exhibits a high degree of heterogeneity at histological and clinical level and an augmented number of mutations [2,4-6]. The complexity of melanoma, particularly when metastasis occurs, makes it exceedingly difficult to treat. In the last decade, the treatment of metastatic melanoma has known a great development by the introduction of immunotherapy such as inhibitors of BRAF, CTLA 4 (cytotoxic T-lymphocyte antigen-4) and PDI (programmed death-I) with promising results $[\mathrm{I}, 2,5,6]$. Still, these compounds were associated with multiple immune adverse reactions and another inconvenient is represented by the fact that not all patients can tolerate this kind of treatment. Besides the increased rate of response to single or combined immunotherapy, the durability of the response could be considered a variable in the light of melanoma cells' ability to develop drug resistance $[1,2,5]$. Novel strategies are required to enhance the effectiveness of the existent treatment and to overcome the potential drawbacks.

A hallmark of cancer, and particularly of solid tumors including melanoma, is represented by angiogenesis also known as tumor neovascularization that implies the formation of novel blood vessels from an existent vascular system [7-9]. Tumor-associated angiogenesis requires a constant activation due to the high demand of the uncontrollable proliferation tumor cells, whereas in physiological conditions (as wound healing) is an incidental process, and it is considered a pivotal factor due to its involvement in the formation of primary tumor, tumor survival, and in the development of metastases $[7,8,10]$. In cutaneous melanoma, angiogenesis is vital for the transition from radial to vertical growth phase and could be used as an indicator of the aggressiveness of the tumor, a highly vascularized tumor being correlated with poor prognosis $[8,9]$. The existing knowledge regarding tumor-associated angiogenesis converts this process into an important therapeutic target, significant steps being performed in this direction with the novel antiangiogenic agents, but in the case of malignant melanoma, the response to antiangiogenic therapy is rather low. A possible explanation is the vascular mimicry (melanoma cells invade the endothelial cellular network and simulate the endothelial cell functions) or the capacity of melanoma cells to evade blood stream and to grow along the existent blood vessels [ro]. This different behavior of melanoma cells in terms of angiogenesis as compared to other solid tumors makes it exceedingly difficult to treat and finding new therapeutic approaches becomes mandatory.

A potential therapeutic alternative for the treatment of melanoma could be considered betulinic acid (BA), a natural molecule, member of the triterpenes pentacyclic family, that attracted an increased interest in recent years due to its broad spectrum of biological effects as antitumor, antiangiogenic, anti-inflammatory, immunomodulatory, antiviral, antidiabetic, antihyperlipidemic, hepatoprotective, etc. [II-I5]. The potent anticancer effect proved against multiple tumor cells of different origin (melanoma, breast cancer, neuroblastoma, glioblastoma, lung cancer, colorectal carcinoma, prostate carcinoma, hepatocellular carcinoma, pancreatic cancer, etc.) [13] together with the very low/absent degree of toxicity exerted in normal cells make this compound a reliable candidate as anticancer agent [II]. Significant insights were taken into the underlying mechanism of BA antitumor activity: (i) inductor of apoptosis via mitochondrial intrinsic pathway; (ii) regulator of cell cycle and angiogenic pathway by suppressing the expression of the specificity protein-Sp transcription factors-SpI, Sp3 and Sp4, of EGFR - epidermal growth factor receptor, cyclin Di and VEGF expression; (iii) modulator of NF- $\mathrm{KB}$ activity, and (iv) antimetastatic effect via inhibition of epithelial-to-mesenchymal transition [II,I3,I6]; still, it is far from being completely elucidated. 
In the light of the facts stated above, this study aims to verify the effect of betulinic acid (BA) as an antimelanoma agent in vitro by exerting a multitarget potential: cytotoxic in human $\left(\mathrm{A}_{375}\right)$ melanoma cell line and antiangiogenic on an in ovo melanoma model.

\section{Materials and Methods}

\section{Reagents}

The reagents used in the study were of analytical-grade purity and suitable for cell culture conditions. Betulinic acid (purity (HPLC) $\geq 98 \%$ ), dimethyl sulfoxide (DMSO_purity (GC) $\geq 99.9 \%$ ), phosphate saline buffer (PBS), Trypan blue (purity (HPLC) $\geq 80 \%$ ), trypsin-EDTA solution, MTT cell proliferation kit I (code: II4650070or, Roche) were purchased from Sigma Aldrich, Merck KGaA. The cell culture medium-Dulbecco's Modified Eagle's Medium (DMEM) and the other reagents used for cell culture-fetal bovine serum (PBS), antibiotics mixture, were bought from ATCC and Thermo Fisher Scientific (Waltham, MA, USA).

\section{Cell Lines}

To perform the experiments assigned for the present study was used a human melanoma cell line- $\mathrm{A}_{375}$ (ATCC ${ }^{\circ}$ CRL-I6r9 ${ }^{\mathrm{TM}}$ ) acquired as frozen item from American Type Culture Collection (ATCC). This cell line is an immortalized cell line, with adherent growth properties, epithelial morphology (a detailed characterization of the cell line can be found on the manufacturer site)), and classified as Biosafety level I (present minimal potential risk both to laboratory personnel and the environment) [I7].

\section{Cell Culture}

A375 melanoma cells require the following cell growth conditions: a specific culture medium-Dulbecco's Modified Eagle's Medium (DMEM-ATCC $30-2002^{\mathrm{TM}}$ ) high glucose- $4500 \mathrm{mg} / \mathrm{L}$ enriched with $10 \%$ fetal bovine serum (FBS) and $\mathrm{I} \%$ mixture of antibiotics (Penicillin and Streptomycin) to avoid cells' contamination. Through the experiments, the cells were incubated in standard conditions $\left(\right.$ at $37^{\circ} \mathrm{C}$ and $5 \% \mathrm{CO}_{2}$ ) and cultured according to the manufacturers' recommendations. The cells were counted automatically by the means of Countess $^{\mathrm{TM}}$ II Automated Cell Counter and Trypan blue.

\section{Cell Viability Determination}

The cytotoxic effect of BA on $\mathrm{A}_{375}$ cells was assessed by the means of a standard cell viability assay-MTT (3-(4,5-Dimethylthiazol-2-yl)-2,5-Diphenyltetrazolium Bromide) that is applied to measure the metabolic activity of the cells as a marker of cell viability and cytotoxicity. The experimental protocol applied consisted of the following steps: (I) cells' seeding ( $\mathrm{IO}^{4}$ cells $/ 200 \mu \mathrm{L}$ medium/well) in 96 -well plates overnight; (2) stimulation of cells with increasing concentrations of BA in DMSO (I, 5, IO, 25, 50 and $75 \mu \mathrm{M}$ ) in fresh culture medium for $72 \mathrm{~h}$; (3) at $72 \mathrm{~h}$ post-treatment it was added Io $\mu \mathrm{L}$ MTT reagent/well and incubated for $3 \mathrm{~h}$ at $37^{\circ} \mathrm{C}$, followed by addition of roo $\mu \mathrm{L}$ of solubilization buffer/well and maintenance at room temperature and dark for 30 minutes; and (4) absorbance values measurement at $570 \mathrm{~nm}$ using a microplate reader (xMark ${ }^{\mathrm{TM}}$ Microplate, Bio-Rad, CA, USA). The obtained data are expressed as the mean $\%$ of viable cells compared to the control \pm SD (each concentration was tested in triplicate). The control cells were considered the cells stimulated with the solvent-DMSO. 


\section{Microscopical Evaluation of Melanoma Cells Morphology}

The potential changes in melanoma cells morphology induced by BA treatment for $72 \mathrm{~h}$ were monitored and photographed under bright light illumination of the Olympus IX 73 inverted microscope (Olympus, Tokyo, Japan) equipped with a $\mathrm{DP}_{74}$ camera.

\section{In Ovo Melanoma Model Using the Chorioallantoic Membrane (CAM) Assay}

In order to verify the impact of BA on melanoma angiogenesis process it was obtained an in ovo model of human melanoma using $\mathrm{A}_{375}$ melanoma cells and CAM assay.

For this experimental part, white chicken eggs acquired from local providers were used. The in ovo melanoma model was performed according to the experimental protocol described by the literature and adapted to our laboratory conditions with slight modifications [18,19]. In brief, the basic protocol consisted of the following steps: (I) egg disinfection with ethanol and incubation at $37^{\circ} \mathrm{C}$ and controlled humidity; (2) aspiration of approximately $5 \mathrm{~mL}$ of albumen (day 3 of incubation); (3) opening of resealable windows on the upper side of the eggs (day 4 of incubation); (4) inoculation of $\mathrm{A}_{375}$ cells ( $\left(\mathrm{O}^{5} \mathrm{cells} / 3 \mu \mathrm{L}\right.$ culture medium) on the ioth day of incubation inside plastic rings disposed on the CAMs.

On the following day (o h), test (IomM BA in DMSO) and control (I\% DMSO) solutions were applied inside the rings on top of the CAMs containing melanoma cells. Daily, $3 \mu \mathrm{L}$ of samples were applied onto the developing specimens. In ovo stereomicroscopic (Discovery 8 Stereomicroscope, Zeiss, Göttingen, Germany) observation, after 72 and $96 \mathrm{~h}$, focused on changes in the tumor-associated vascular response next to alteration of tumor development. Relevant images were captured using the Axio CAM ros color, Zeiss digital camera and processed by Zeiss ZEN software, ImageJ and GIMP. All experiments were performed in triplicate.

\section{Statistical Analysis}

The statistical analysis of the obtained results was performed using Graph Pad Prism 8 software. One-way ANOVA statistical test was applied to define the statistical differences between the BA and DMSO-treated cells followed by Dunnett's post-test $\left.{ }^{* * * *} p<0.000 \mathrm{I}\right)$. The data are expressed as mean values \pm standard deviation (SD).

\section{Results}

\section{BA Treatment for 72 b Triggered a Marked Cell Death in A375 Melanoma Cells}

Treatment of A375 melanoma cells with BA in DMSO solution (I, 5, I0, 25, 50 and $75 \mu \mathrm{M}$ ) for $72 \mathrm{~h}$ led to a concentration-dependent decrease of cells' viability (Figure I). A statistically significant reduction of cells viability percentage (6r.95\%) was observed even at the lowest concentration tested- $\mathrm{r} \mu \mathrm{M}$, the values of viability percentage at the highest concentration $-75 \mu \mathrm{M}$ being lower than $20 \%$. The calculated IC 50 was $9.437 \mu \mathrm{M}$. 


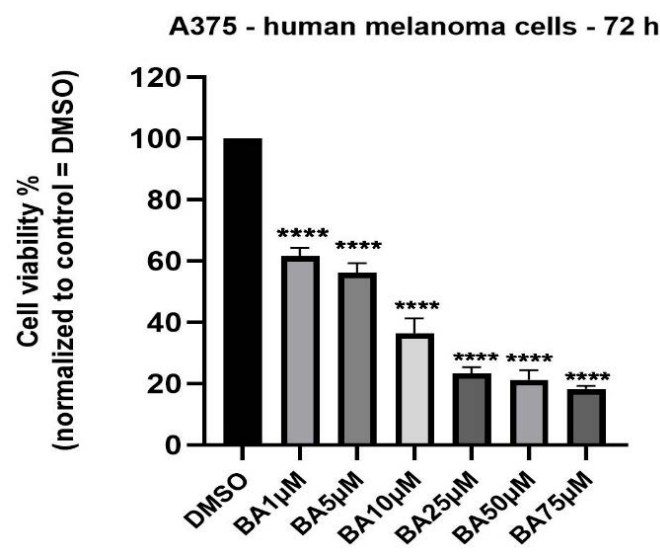

Figure 1. In vitro assessment of BA impact (I, 5, 10, 25, 50 and $75 \mu \mathrm{M}$ ) on viability of $\mathrm{A}_{375}$ cells at $72 \mathrm{~h}$ post-stimulation by the MTT cell viability assay. The results are expressed as cell viability percentage (\%) normalized to DMSO-stimulated (the solvent used for BA) cells. The data represent the mean values $\pm \mathrm{SD}$ of three independent experiments performed in triplicate. One-way ANOVA analysis was applied to determine the statistical differences compared with the control (DMSO) group, followed by Dunnett's multiple comparisons post-test $\left.{ }^{* * * *} p<0.000 \mathrm{I}\right)$.

\section{BA Treatment for $72 \mathrm{~b}$ Induced Morphological Changes in A375 Melanoma Cells}

The cytotoxic effect of a compound can be also evaluated by the changes induced in cellular morphology. Following this line, were monitored microscopically the morphological changes induced by BA treatment in A 375 cells after $72 \mathrm{~h}$. As it can be noticed in Figure 2, BA induced significant changes in cells' shape, adherence to the plate and confluency in a concentration-dependent manner. At the lowest concentration tested $-\mathrm{I} \mu \mathrm{M}$ were observed round cells floating in the culture medium, still the confluency was not markedly affected. Starting with $25 \mu \mathrm{M}, \mathrm{BA}$ induced significant changes in cells morphology as round shape, extremely low adherence to the plate and a reduced confluency, and at the highest concentration- $75 \mu \mathrm{M}$ cellular debris was predominant. DMSO treatment induced morphological changes only at the highest concentrations - 50 and $75 \mu \mathrm{M}$ as round cells that floated within the culture medium, but the confluency was not markedly affected as in the case of BA-treated cells. These data confirm the cell viability results.

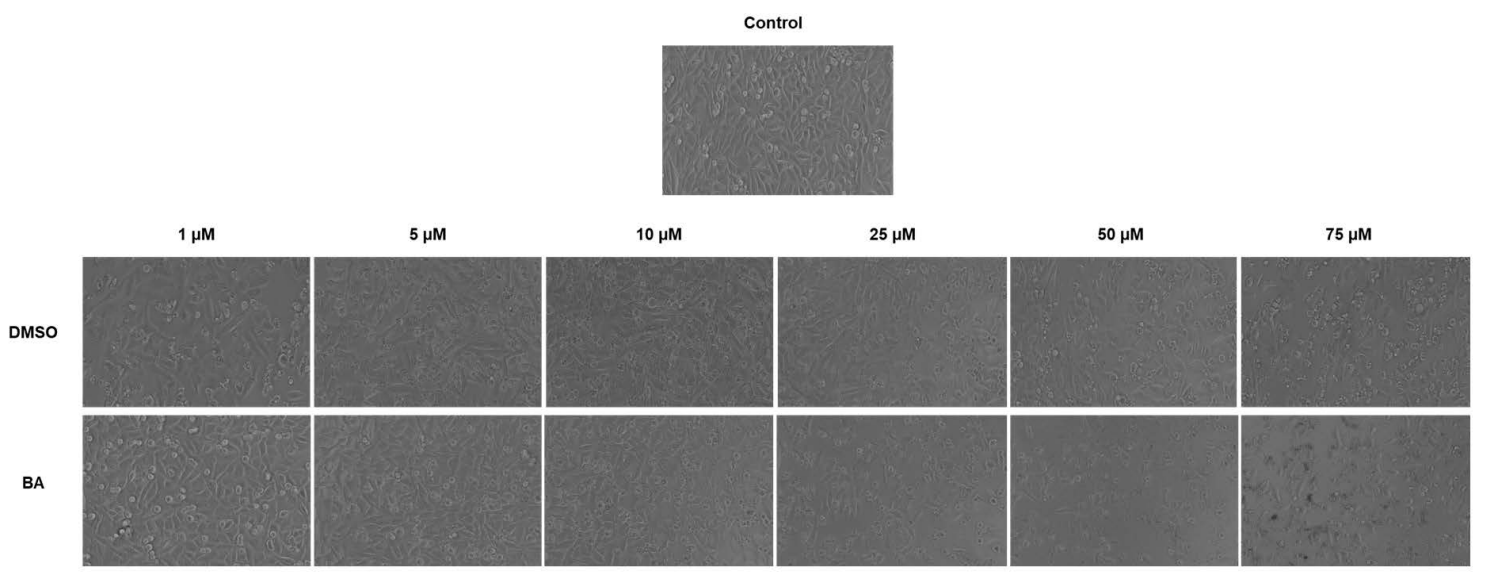

Figure 2. Microscopical aspect of $A_{375}$ human melanoma cells after BA (I, 5, 10, 25, 50 and $75 \mu \mathrm{M}$ ) and DMSO treatment for $72 \mathrm{~h}$. The pictures were taken using the Iox objective. 


\section{BA Effects on Melanoma Angiogenesis In Ovo}

We investigated in ovo the influence of $\mathrm{BA}$ on tumoral angiogenic process, including on $\mathrm{A}_{375}$ melanoma cells development. The evaluation was performed compared to the solvent control, diluted DMSO. No signs of toxicity were noted up to $72 \mathrm{~h}$ after treatment, in neither test nor control applied samples. The viability of the specimens was reduced after this period, registering a higher death rate of the specimens at $96 \mathrm{~h}$ post treatment.

In the first days after application, BA did not influence tumor angiogenesis at an important degree, showing a spokes wheel aspect outside the ring, and especially towards the migrating tumor tissue, but not inside the ring. At 72 and $96 \mathrm{~h}, \mathrm{BA}$ induced a reduction of the primary tumor mass development, and a limited vascular reaction (Figure 3). In contrast, a limited effect on the forming secondary tumor areas could be observed. BA did not influence the invasiveness of tumor cells, and secondary tumors were observed. Still, when BA was applied directly on secondary formed tumors, melanoma growth was reduced. BA exerted an inhibitory effect both on $\mathrm{A}_{375}$ cells growth and angiogenesis at the primary site after $72 \mathrm{~h}$ post application, while allowing the formation of secondary tumors, well vascularized peritumoral but not intratumorally, compared to the control specimens.

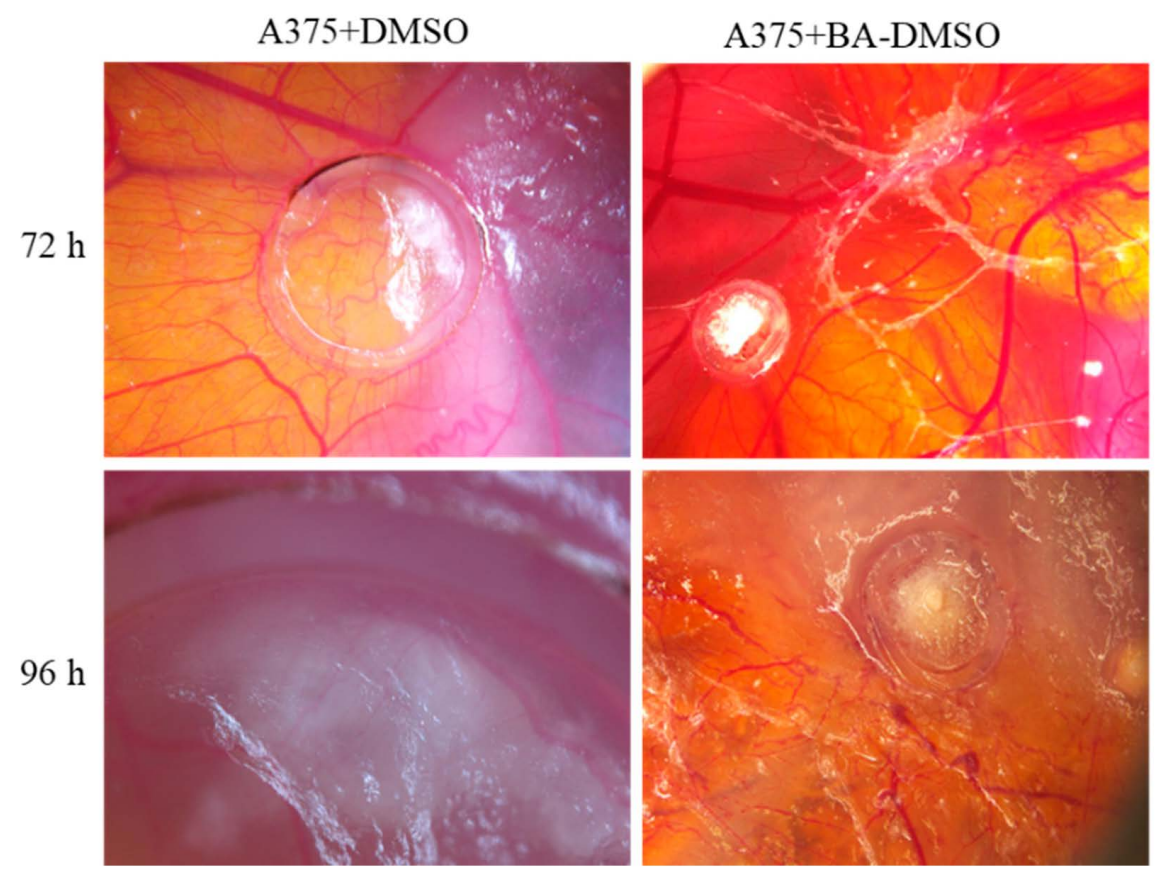

Figure 3. BA treatment impact on $A_{375}$ melanoma cell graft and tumor formation on chick embryo chorioallantoic membrane (CAM) by the means of stereomicroscopy.

\section{Discussion}

The intricacy of melanoma as concerns the cellular, biochemical, genetic and immunological events underlying its development, progression and metastasis sets this pathology among the most challenging type of cancer in terms of treatment $[4,6]$. Even if the results of the latest strategies applied for the treatment of metastatic melanoma are promising, there is still a major drawback considering the well-known capacity of melanoma cells to evade cell death and acquire resistance to treatment. Multiple directions of research were initiated in the field of metastatic melanoma treatment including the assessment of natural compounds for 
anticancer properties that gained an increased interest due to the multiple pharmacological effects exhibited and the reduced adverse effects.

The present study was developed to verify the antimelanoma properties of BA, a pentacyclic triterpene with lupan skeleton, by assessing its cytotoxic potential in a human melanoma cell line- $\mathrm{A}_{375}$ and its ability to suppress tumor angiogenesis, a key process in melanoma progression and metastasis. The $\mathrm{A}_{375}$ melanoma cell line was selected as model for the in vitro cytotoxicity assessments based on $\mathrm{A}_{375}$ cells ability to keep the features of the human genitor and to present $\mathrm{B}-\mathrm{RAF}$ and $\mathrm{CDKN}_{2}$ mutations, specific for cutaneous melanoma [18].

Betulinic acid (3ß-Hydroxy-lup-2o(29)-en-28-oic acid), a bioactive compound of natural origin, has been subjected to multiple pharmacological studies in the last two decades; the first study acknowledging the antimelanoma activity of BA was conducted by Pisha et al. which began in 1995 [20]. Further studies proved the in vitro antimelanoma properties of $\mathrm{BA}$, not only as single agent $[\mathrm{I} 6,2 \mathrm{I}-26]$ but also in combination with gamma irradiation [2I] or vincristine [27]. The cytotoxicity results observed after BA treatment in melanoma cells described in the abovementioned studies $[16,21,22]$ support our results. Besides the antimelanoma effect, BA also showed potent anticancer activity against multiple tumor cells, as: breast cancer, glioblastoma, lung cancer, colorectal carcinoma, prostate carcinoma, pancreatic cancer, neuroblastoma, etc. [I2,I3,28].

Our results indicate a cytotoxic effect of BA dependent on concentration, but based on the data obtained in our previous study [16] that showed a marked cytotoxic effect of BA in $A_{375}$ cells only at $50 \mu \mathrm{M}$ after $24 \mathrm{~h}$, it could be stated that the effect is also time dependent ( $1 \mu \mathrm{M} \mathrm{BA}$ at $72 \mathrm{~h}$ reduced the $\mathrm{A}_{375}$ percentage cells viability at 6r.95\%-see Figure I). Suresh and collaborators also proved a dose dependent cytotoxic effect of BA in $\mathrm{A}_{375}$ cells after 24 and $48 \mathrm{~h}$ stimulation with an IC50 value of $154 \mu \mathrm{M}$ [29]. Treatment of $\mathrm{A}_{375}$ cells with BA solution (o-I0o $\mu \mathrm{M})$ for $96 \mathrm{~h}$ determined a marked cytotoxicity and an IC50 of $\mathrm{I}_{3.3} \mu \mathrm{M}$ [30], a value significantly lower as compared to the value obtained by Suresh et al. after 24 and $48 \mathrm{~h}\left(\mathrm{IC}_{50}=\mathrm{I}_{54} \mu \mathrm{M}\right)$, which indicates the BA induces a time-dependent cytotoxicity. These data are in agreement with our results.

The chick chorioallantoic membrane (CAM) assay is frequently applied as a pre-screening experimental model for the study of cancer (in terms of tumor aggressiveness, angiogenesis, efficacy of a novel chemotherapeutic agent) that can be applied not only for melanoma, but also for other types of cancer like thyroid cancer [18,3I]. This method presents several advantages as compared to mouse models, such as the development of the primary tumor requiring a shorter time, reduced costs, reliable results, multiple evaluations concurrently, and does not require ethical approval since, according to the $\mathrm{EU}$, it is considered as a non-animal method that respects the ${ }_{3} \mathrm{R}$ criteria (replace, reduce, refine) [I8,3I].

To the best of our knowledge, the findings regarding the antiangiogenic effect of $\mathrm{BA}$ in melanoma are rather missing, but there is described the antiangiogenic mechanism of action in breast cancer $[27,28]$, prostate cancer $[32,33]$, and pancreatic cancer [34]. An antiangiogenic effect of BA was also shown in human endometrial adenocarcinoma cells by suppressing prolidase, HIF-I $\alpha$ and VEGF expressions [35], and in human colorectal cells by down-regulating VEGF expression [36].

Our results indicate that treatment with BA impaired the in ovo tumor growth. Concerning the melanoma-associated angiogenesis, BA proved an inhibitory effect but only on the primary tumor angiogenesis (see Figure 3). The antiangiogenic potential of BA was previously assessed by our group concerning the effect on normal angiogenesis as a preliminary evaluation for tumor treatment application. Direct antiangiogenic effect on endothelial cells next to rapid vessel maturation was described in ovo [37]. 


\section{Conclusions}

The present study has shown that BA induced a concentration-dependent cytotoxicity in $\mathrm{A}_{375}$ melanoma cells by reducing cells' viability and triggering morphological changes. In addition, BA exhibited an inhibitory effect on the in ovo tumor growth and suppressed the angiogenesis associated to the primary tumor. These results represent the basis for further mechanistic elucidation of BA-suppressed angiogenesis and to characterize its anti-invasive and antimetastatic potential.

Author Contributions: Conceptualization, D.C., S.A. and C.D.; Methodology, D.C., S.A., I.M.; Software, I.M. and I.P.; Writing-Original Draft Preparation, D.C, I.M., I.P. and S.A; Writing-Review \& Editing, D.C., C.D., C.S.; Supervision, C.D. and C.S.; Project Administration, C.D.; Funding Acquisition, D.C.

Funding: The present study was supported by the Executive Agency for Higher Education, Research, Development and Innovation Funding Institution [grant no. PN-III-PI-I.I-PD-20I6-I982] and the grant was awarded to D.C.

Conflicts of Interest: The authors declare no conflict of interest.

\section{References}

I. Jenkins, R.W.; Fisher, D.E. Treatment of Advanced Melanoma in 2020 and Beyond. J. Investig. Dermatol. 2020. [CrossRef]

2. Davis, L.E.; Shalin, S.C.; Tackett, A.J. Current state of melanoma diagnosis and treatment. Cancer Biol. Ther. 2019, 20, i366-1379. [CrossRef] [PubMed]

3. National Cancer Institute. Cancer Stat Facts: Melanoma of the Skin; National Cancer Institute: USA, 2019.

4. Coricovac, D.; Dehelean, C.A.; Moacă, E.-A.; Pinzaru, I.; Bratu, T.; Navolan, D.; Boruga, O. Cutaneous Melanoma-A Long Road from Experimental Models to Clinical Outcome: A Review. Int. J. Mol. Sci. 2018, 19, i566. [CrossRef] [PubMed]

5. Ralli, M.; Botticelli, A.; Visconti, I.C.; Angeletti, D.; Fiore, M.; Marchetti, P.; Lambiase, A.; De Vincentiis, M.; Greco, A. Immunotherapy in the Treatment of Metastatic Melanoma: Current Knowledge and Future Directions. J. Immunol. Res. 2020, 2020, 9235638. [CrossRef] [PubMed]

6. Leonardi, G.C.; Candido, S.; Falzone, L.; Spandidos, D.A.; Libra, M. Cutaneous melanoma and the immunotherapy revolution (Review). Int. J. Oncol. 2020, 57, 609-6r8. [CrossRef] [PubMed]

7. Emmett, M.S.; Dewing, D.; Pritchard-Jones, R.O. Angiogenesis and melanoma-From basic science to clinical trials. Am. J. Cancer Res. 2011, 1, 852-868.

8. Cho, W.C.; Jour, G.; Aung, P.P. Role of angiogenesis in melanoma progression: Update on key angiogenic mechanisms and other associated components. Semin. Cancer Biol. 2019, 59, 175-186. [CrossRef]

9. Castet, F.; Garcia-Mulero, S.; Sanz-Pamplona, R.; Cuellar, A.; Casanovas, O.; Caminal, J.M.; Piulats, J.M. Uveal Melanoma, Angiogenesis and Immunotherapy, Is There Any Hope? Cancers 2019, 11, 834. [CrossRef]

ıo. Felcht, M.; Thomas, M. Angiogenesis in malignant melanoma. J. Dtsch. Dermatol. Ges. 2015, 13, I25-I35. [CrossRef]

II. Kumar, P.; Bhadauria, A.S.; Singh, A.K.; Saha, S. Betulinic acid as apoptosis activator: Molecular mechanisms, mathematical modeling and chemical modifications. Life Sci. 2018, 209, 24-33. [CrossRef]

I2. Chairez-Ramirez, M.H.; Jiménez, M.R.; González-Laredo, R.F.; Gallegos-Infante, J.; Rocha-Guzmán, N. Lupane-type triterpenes and their anti-cancer activities against most common malignant tumors: A review. EXCLIJ. 2016, 15, 758-77I.

13. Zhang, X.; Hu, J.; Chen, Y. Betulinic acid and the pharmacological effects of tumor suppression (Review). Mol. Med. Rep. 2016, 14, 4489-4495. [CrossRef]

I4. Ríos, J.L.; Máñez, S. New Pharmacological Opportunities for Betulinic Acid. Planta Medica 2017, 84, 8-19. [CrossRef]

15. Seca, A.M.L.; Pinto, D.C.G.A. Plant Secondary Metabolites as Anticancer Agents: Successes in Clinical Trials and Therapeutic Application. Int. J. Mol. Sci. 2018, 19, 263. [CrossRef]

16. Gheorgheosu, D.; Jung, M.; Ören, B.; Schmid, T.; Dehelean, C.; Muntean, D.; Brüne, B. Betulinic acid suppresses NGAL-induced epithelial-to-mesenchymal transition in melanoma. Biol. Chem. 2013, 394, 773-78I. [CrossRef]

17. Chosewood, L.C.; Wilson, D.E. Biosafety in Microbiological and Biomedical Laboratories, 5th ed.; U.S. Department of Health and Human Services, Public Health Services, Centers for Disease Control and Prevention National Institutes of Health: USA, 2009. 
18. Avram, S.; Coricovac, D.-E.; Pavel, I.Z.; Pinzaru, I.; Ghiulai, R.; Baderca, F.; Soica, C.; Muntean, D.; Branisteanu, D.E.; Spandidos, D.A.; et al. Standardization of A 375 human melanoma models on chicken embryo chorioallantoic membrane and Balb/c nude mice. Oncol. Rep. 2017, 38, 89-99. [CrossRef]

19. Ribatti, D. The chick embryo chorioallantoic membrane (CAM). A multifaceted experimental model. Mech Dev. 2016, 141, 70-77. [CrossRef]

20. Pisha, E.; Chai, H.; Lee, I.-S.; Chagwedera, T.E.; Farnsworth, N.R.; Cordell, G.A.; Beecher, C.W.; Fong, H.H.; Kinghorn, A.D.; Brown, D.M.; et al. Discovery of betulinic acid as a selective inhibitor of human melanoma that functions by induction of apoptosis. Nat. Med. 1995, 1, I046-I05I. [CrossRef]

2I. Selzer, E.; Pimentel, E.; Wacheck, V.; Schlegel, W.; Pehamberger, H.; Jansen, B.; Kodym, R. Effects of Betulinic Acid Alone and in Combination with Irradiation in Human Melanoma Cells. J. Investig. Dermatol. 2000, 114, 935-940. [CrossRef]

22. Raisova, M.; Hossini, A.M.; Eberle, J.; Riebeling, C.; Wieder, T.; Sturm, I.; Daniel, P.T.; Orfanos, C.E.; Geilen, C.C. The Bax/Bcl-2 ratio determines the susceptibility of human melanoma cells to $\mathrm{CD}_{95} /$ Fas-mediated apoptosis. J. Investig. Dermatol. 2001, 117, 333-340. [CrossRef]

23. Wachsberger, P.R.; Burd, R.; Wahl, M.L.; Leeper, D.B. Betulinic acid sensitization of low pH adapted human melanoma cells to hyperthermia. Int. J. Hyperth. 2002, 18, 153-164. [CrossRef] [PubMed]

24. Tan, Y.; Yu, R.; Pezzuto, J.M. Betulinic acid-induced programmed cell death in human melanoma cells involves mitogen-activated protein kinase activation. Clin. Cancer Res. 2003, 9, 2866-2875.

25. Kessler, J.H.; Mullauer, F.B.; De Roo, G.M.; Medema, J.P. Broad in vitro efficacy of plant-derived betulinic acid against cell lines derived from the most prevalent human cancer types. Cancer Lett. 2007, 251, I32-I45. [CrossRef]

26. Weber, L.A.; Meissner, J.; Delarocque, J.; Kalbitz, J.; Feige, K.; Kietzmann, M.; Michaelis, A.; Paschke, R.; Michael, J.; Pratscher, B.; et al. Betulinic acid shows anticancer activity against equine melanoma cells and permeates isolated equine skin in vitro. BMC Vet. Res. 2020, 16, 44-9. [CrossRef] [PubMed]

27. Zeng, A.-Q.; Yu, Y.; Yao, Y.-Q.; Yang, F.-F.; Liao, M.; $\square$ Song, L.-J.; Li, Y.-L.; Li, Y.-J.; Deng, Y.-L.; Yang, S.-P.; et al. Betulinic acid impairs metastasis and reduces immunosuppressive cells in breast cancer models. Oncotarget 2017, 9, 3794-3804. [CrossRef]

28. Luo, R.; Fang, D.; Chu, P.; Wu, H.; Zhang, Z.; Tang, Z. Multiple molecular targets in breast cancer therapy by betulinic acid. Biomed. Pharmacother. 2016, 84, I32I-I330. [CrossRef]

29. Suresh, C.; Zhao, H.; Gumbs, A.; Chetty, C.S.; Bose, H.S. New ionic derivatives of betulinic acid as highly potent anti-cancer agents. Bioorg. Med. Chem. Lett. 2012, 22, I734-I738. [CrossRef] [PubMed]

30. Liebscher, G.; Vanchangiri, K.; Mueller, T.; Feige, K.; Cavalleri, J.M.V.; Paschke, R. In vitro anticancer activity of Betulinic acid and derivatives thereof on equine melanoma cell lines from grey horses and invivo safety assessment of the compound NVX-207 in two horses. Chem. Interact. 2016, 246, 20-29. [CrossRef]

31. Ghaffari-Tabrizi-Wizsy, N.; Passegger, C.A.; Nebel, L.; Krismer, F.; Herzer-Schneidhofer, G.; Schwach, G.; Pfragner, R. The avian chorioallantoic membrane as an alternative tool to study medullary thyroid cancer. Endocr. Connect. 2019, 8, 462-467. [CrossRef] [PubMed]

32. Chintharlapalli, S.; Papineni, S.; Ramaiah, S.K.; Safe, S. Betulinic Acid Inhibits Prostate Cancer Growth through Inhibition of Specificity Protein Transcription Factors. Cancer Res. 2007, 67, 2816-2823. [CrossRef]

33. Shin, J.; Lee, H.-J.; Jung, D.-B.; Jung, J.H.; Lee, E.-O.; Lee, S.G.; Shim, B.S.; Choi, S.H.; Ko, S.G.; Ahn, K.S.; et al. Suppression of STAT 3 and HIF-I Alpha Mediates Anti-Angiogenic Activity of Betulinic Acid in Hypoxic PC-3 Prostate Cancer Cells. PLoS ONE 2011, 6, e2I492. [CrossRef]

34. Gao, Y.; Jia, Z.; Kong, X.; Li, Q.; Chang, D.Z.; Wei, D.; Le, X.; Suyun, H.; Huang, S.; Wang, L.; et al. Combining betulinic acid and mithramycin a effectively suppresses pancreatic cancer by inhibiting proliferation, invasion, and angiogenesis. Cancer Res. 2011, 71, 5182-5193. [CrossRef]

35. Karna, E.; Szoka, L.; Palka, J. Betulinic acid inhibits the expression of hypoxia-inducible factor $\mathrm{\alpha} \alpha$ and vascular endothelial growth factor in human endometrial adenocarcinoma cells. Mol. Cell. Biochem. 2010, 340, i5-20. [CrossRef]

36. Ren, W.; Qin, L.; Xu, Y.; Cheng, N. Inhibition of betulinic acid to growth and angiogenesis of human colorectal cancer cell in nude mice. Chin.-German J. Clin. Oncol. 2010, 9, I53-I57. [CrossRef]

37. Dehelean, C.A.; Feflea, S.; Ganta, S.; Amiji, M. Anti-angiogenic effects of betulinic acid administered in nanoemulsion formulation using chorioallantoic membrane assay. J. Biomed. Nanotechnol. 2011, 7, 317-324. [CrossRef]

(C) 2020 Copyright by the authors. Licensed as an open access article using a CC BY 4.0 license.

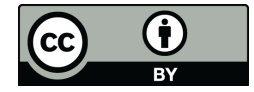

